Saudi Journal of Humanities and Social Sciences

Abbreviated Key Title: Saudi J Humanities Soc Sci

ISSN 2415-6256 (Print) | ISSN 2415-6248 (Online)

Scholars Middle East Publishers, Dubai, United Arab Emirate

Journal homepage: http://scholarsmepub.com/shihs/

Original Research Article

\title{
The Meaning of "Small Step Gives a Change" Version of Ades Corporate Social Responsibility Advertisement in Television Media
}

\author{
Enjang Pera Irawan* \\ Fakultas Ilmu Komunikasi Universitas Mercu Buana, Jl. Meruya Selatan No.1, RT.4/RW.1, Meruya Sel., Kec. Kembangan, Kota Jakarta Barat, Daerah \\ Khusus Ibukota Jakarta 11650, Indonesia
}

DOI: $\underline{10.36348 / \text { sjhss.2019.v04i12.006 }}$

| Received: 21.10.2019 | Accepted: 28.10.2019 | Published: 30.12.2019

*Corresponding author: Enjang Pera Irawan

\section{Abstract}

This study is entitled the meaning of "small step gives a change" version of ADES corporate social responsibility advertisement in television media. The purpose of this study is to uncover the meaning contained in an advertisement. This research is expected to give scientific contributions for all parties that have an interest in communication practitioners. In addition, this research also hopefully gives contributions of thoughts relating to the application and advertisement creation that have the right meaning and message through the audio visual language of CSR advertisements in television media, so that the Advertising messages can touch the rational and emotional aspects of the audience. The method used in this research was a semiotic analysis method of Charles Sanders Pierce. The object of study in this study was the ADES mineral water advertisement of "Small Step Gives a Change" version in television media which has seventeen seconds time duration. Based on research that has been obtained on the results of research and discussion on the meaning of the messages contained in the ADES mineral water advertisement of "Small Step Gives a Change" version on television media, it can be concluded that through the finding of signs in Ades advertisement, it was implied a message about the environment care. Ades wanted to show that the mineral water had a high quality and gave solutions to the public in protecting the body. Broadly speaking, the advertisements' meaning show the commitment of Coca-Cola Amatil Indonesia towards sustainable packaging. The sustainable means that through the environmentally and friendly ADES packaging, it can have a positive impact on the environment sustainiblity.

Keywords: Semiotic, Adverstisement meaning, CSR Adverstisement, \& Television media.

Copyright @ 2019: This is an open-access article distributed under the terms of the Creative Commons Attribution license which permits unrestricted use, distribution, and reproduction in any medium for non-commercial use (NonCommercial, or CC-BY-NC) provided the original author and source are credited.

\section{INTRODUCTION}

In the midst of global warming issue, various organizations, institutions, communities, and companies with the environmental themes have emerged. Some movements and campaigns have been carried out to invite the people for saving the earth together such as, planting trees, conserving nature, saving electricity, and so on. Likewise, some beverage companies do as well. Most of them carry out a series of campaigns and social activities as one of their social responsibilities towards the nature and human being.

The bottled drinking water compsumstion in Indonesia has become something normal. It is undeniable that, nowadays, there are a lot of selling bottled drinking water. Thus, there are a lot of competitive behavior in producing drinking water that is suitable for public consumption. Some call it mineral drinking water, even, there were also pure drinking water with varying qualities. One of the bottled drinking water products that also enlivens the market share in Indonesia is Ades. Ades bottled water is one of the products released by Coca Cola Amatil Indonesia (CCAI), one of the largest companies in Indonesia, which started to carry out environmental issues in promoting the products.

In producing the environmentally and friendly product innovation, Coca Cola Amatil Indonesia (CCAI), a distributor in Indonesia is trying to increase awareness of its consumers who can provide change for our earth. By releasing mineral water products such ADES in 2012, CCAI also has a campaign to minimize the use of plastic by launching a thinner mineral water package. In addition, Ades also campaigns for "how to enjoy" the packaging. Not only through selling its products, CCAI also carries out other social activities in the fields of education, greening, and other movements. 
Not a few companies use mass media to strengthen their image and reputation. The mass media has power and effective "power tool" to attract public attention directly, persuade public opinion and beliefs or influence behavior, give status and legitimacy, and explain and structure social perceptions and realities. The mass media is also a place where people can get information and exchange ideas and opinions. Therefore, the role of mass media is very important and fast in following the development of communication technology.

A television is the most recent electronic mass media presence. Nevertheless, television is considered as the most effective electronic mass media and attracts a lot of public sympathy, because the audio-visual character does not belong to the other mass media. Moreover, the broadcast has relatively unlimited reach. By this audio visual model, television broadcast is very communicative in giving their messages. Hence, television is useful as forming attitudes, behaviors, and thought patterns. Nobody disagrees that television advertising is an option in persuading viewers. The power of audio-visual feels very powerful in presenting a demonstrative message. The resulting creations are a combination of engineering techniques with real reality. Therefore, whether or not the audience is influenced, they are determined by extent television advertisements which are able to apply persuasive communication in arousing the interests and desires of the target audience [1].

The mass media has also become a tool for companies to strengthen their image and reputation through advertising. Advertising is a modern business phenomenon. Thus, one of the company's advantages lies in how much funds are allocated for these advertisements. The advertisements often use symbols or signs in describing the products and services offered, it can be seen that there are hidden messages in the advertisement that conveyed the real message. The symbol is in accordance with the agreement or convention of a number of people or the community. The advertisements in the present era represent a phenomenon without having to explain clearly in the advertisement, because the public can already interpret through the symbols in the adverstisement. In addition, an advertisement is a window room of a company. The existence connects the company to the community, especially the consumers.

If viewed and analyzed academically, the advertisement contains messages both implicitly and explicitly in order to reveal the credibility and quality of the company's products. Thus, advertisers make every effort to design not only the content of the message, but also the form of the message. One of them is through CSR (Corporate Social Responsibility) advertising, which is part of public relations practice and wellknown as advertising corporate social responsibility on television media. The understanding of CSR, according to the world business council for sustainable development as an international institution established in 1995, in its publication making good business sense defines CSR as a commitment of the business community to economic improvement. CSR advertising is intended as a marketing tool and corporate branding strategy to add value of the company in the eyes of external stakeholders, especially consumers. The example of CSR advertising is an advertisement which nuanced campaign appeal to invite and motivate audiences in participating positive things or activities through advertisements that are aired.

An advertisement is a semiotic object. Thus, according to Pierce, semiotics is a branch of philosophy that studies the sign (sign), functions as a sign, and also produces a meaning. A sign is something that for someone means something else [2]. Semiotics, according to Charles S. Pierce, is the sign as something inseparable from logic [3]. According to Pierce, in the broadest sense, logic is "thought that takes place through signs" which is equal to general semiotics that does not only review the truth but also the general condition of the sign which becomes a sign. A sign is related to logic, because a sign is a means of thought as an articulation of forms of logic [4]. Pierce proposed a triangle meaning theory or triangle meaning consisting of three main elements, such as, the sign (sign), object, and interpreter.

In advertising, the codes that are clearly readable are language in the form of narrative or textual, audio, and audio-visual elements. In the context of "reading" advertisements in the television media, linking advertisements and semiotics seems to be an interesting research material. Some advertisement impression often do not only offer products, but also attach a certain belief system and values. Advertising on television has become a part of popular culture that produces and represents values and ideologies. The audience seemed to be invited to care about the environment and even himself, such as health, social, and cultural matters. Besides, the audience was invited to consume Ades mineral water. Interestingly the advertising message is no longer just offering goods and services, but also a kind of tool to instill symbolic meaning.

Jib Fowles said that advertising is not just a communication medium. However, the most important thing is the content of the communication concept contained therein, moreover, the concept must be able to represent the intention of producers to publish their products, and the concept must be understood by viewers as intended by the advertisement creator [5]. In addition, the main purpose of an advertising is to communicate messages from the company to its target audience with specific goals and purposes. As defined by Morissan [5], "Advertising is paid non-personal 
communication from an identified sponsor using mass media to persuade or influence an audience" [6].

Based on the background, the researchers used a semiotic analysis on the Ades mineral water product of the Small Step Gives a Change version in Television Media which has seventeen seconds duration. In a white background advertisement, it depicted a man wearing sporty clothes took a bottle of bottled water from the refrigerator and took it to a cool setting and drank the water in the bottle. Furthermore, the man crushed the mineral water bottle into small. The advertisement also added linear steps in consuming bottled mineral water. At the 10th seconds, it slipped a sentence of persuasion with a white background inscribed "small step gives a change". Finally, the last advertisement is a green plant that grow in the broken plastic bottles and Ades logo.

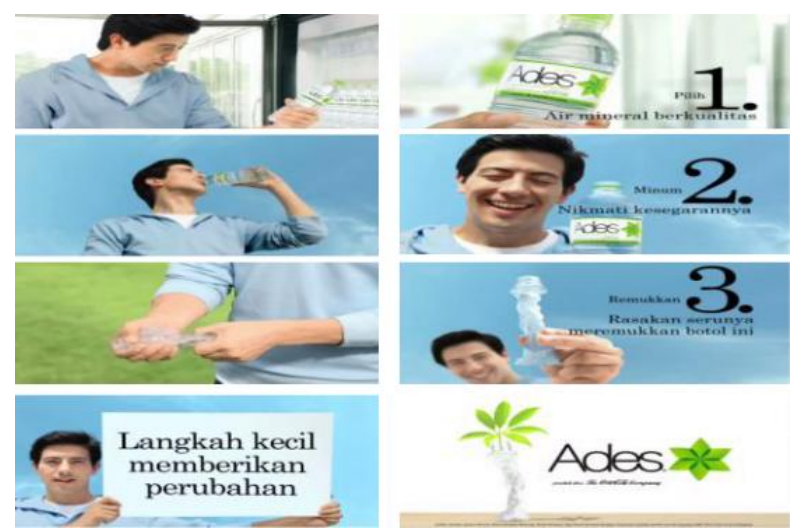

Fig-1: The Screenshot of Ades Advertisement Version "Small step gives a change"

Source:

https://www.youtube.com/watch?v=gX1O02EcsA4

In this study, researchers used a semiotic approach and used the theory of Charles Sander Pierce cited in the book Semiotics communication from Alex Sobur [7], in which Peirce's theory classifies the types of signs into three types; representamen, objects and interpretants that allow researchers to explore the deeper meaning and visual language contained in the Ades mineral water advertisement of "Small Steps Delivering Change" version in Television Media. Ades introduces consumers to a new lifestyle of environmental care through their advertisements with the slogan "Choose-Drink-Crush". Crushing the Ades bottle after drinking will take up less space in the trash, so that, carbon emissions generated when transporting waste become less. Crushing a bottle of mineral water that has been drunk turned out to have a positive impact on the environment.

Based on the background of the problem that have been described previously, the researchers focused this study on the Semiotic Analysis of Ades advertisement of Small Step gives a change version in Television Media. Then, this research is expected to provide some scientific contributions and massages for all parties who have an interest in communication practitioners. In addition, this research contributes the thought relating to the implementation and advertisement creation that have the right meaning and message through the audio visual language of CSR advertisements in television media, so that advertising messages can touch the rational and emotional aspects of the audience.

\section{LITERATURE REVIEW Mass Communication}

The simplest mass communication was stated by Bittner in Rachmat [8] is a message that is communicated through the mass media to a large number of people. From this definition, it can be seen that mass communication must use mass media, even if the communication is conveyed to a large audience such a large public meeting attended by thousands, even tens of thousands of people. If they do not use a mass media, it is not a mass communication. The more detailed definition of mass communication is stated by another communication expert, Gerber. According to Gerber in Rachmat [8], it is a production and distribution based on technology and institutions of the continuous flow of messages and most widely owned by people in the industrial society.

Rachmat summarized the definitions of mass communication into: "mass communication is defined as a type of communication aimed at a number of scattered, heterogeneous, and anonymous audiences through print or electronic media so that the same message can be received simultaneously and for a moment [9]. According to DeFleur in Ells [10], he defines mass communication as " a linear process in which professional communicators [fortunately motivated] use the media to design and disseminate messages [encoded] widely, quickly, and continuously \{long distance\} to evoke the meaning [translated] intended in a large, diverse, and selective audience to influence the audience in various ways"

The existing movements and action groups have successfully used the Internet as a medium of mass communication to reach a larger global audience. In parallel, there has been tremendous growth in the number of independent news providers who have massively communicated their alternative views on current events [11].

\section{Mass Media}

Some researchers in science journalism today see the media as much more than just a communication tool. The selection criteria used by journalists to evaluate and prepare information differ fundamentally from those used in science; the things that are important for a researcher is as important as a journalist and a small detail for a scientist can produce complete media coverage. So, the media do not represent one-on-one science and do not see this as their job. 
Media builds its own reality such a science. It just uses a different way to access the 'reality' and the other methods to present it. The most common complaint voiced by science about 'wrong' or 'crooked' reports or about alleged 'wrong' news choices causes the miss points [12].

Mass media audiences, which ever considered the huge similarities, seem to consist of diverse and active individuals who react in very different ways to the same message [13]. No group is better to exemplify the paradigm of active audiences than partisans, highly involved people who have strong and deep opinions about an issue. For some problems, a large number of people may have a partisan perspective; for other topics that are less important, partisan numbers may be smaller.

However, partisan groups and their members are important beyond their numbers. Their perspective can strongly influence public opinion and public policy; they are people who campaign and lobby, who demonstrate, parade and picket, who promote their viewpoints in countless ways, and when they feel marginalized or alienated, can take extreme or antisocial actions [14].

\section{Advertisement}

The advertisment limitation can be seen as "one form of communication consisting of information and ideas about a product that aimed to get a good reception. Advertising seeks to provide information, persuade, and convince ". Advertising activities, in fact have been started since the ancient Greek and ancient Roman civilizations. Initially, advertisements were carried out in the form of chain messages or the world of mouth. This chain message helped the smooth sale and purchase in the community, which did not recognize letters and only knew the barter system in buying and selling activities. After humans began to use writing as a means of delivering messages, the advertising activities began to use writings or pictures carved on stone, walls or boards [15].

The media routinely provided coverage and levels in recommending products and services, such as books, films, cars, restaurants, computer hardware and software, fashion items, etc., for their readers. Several empirical studies have tried to model the impact of media content based on consumer choice and market outcomes [16]

Many consumers communicate with each other through digital images, symbols and signs, essentially creating a new language in digital communication through an advertisement [17]. The successful economic transactions, the exchange of goods, and services that are mutually beneficial, require trust. As a result, for success advertisement in convincing people to exchange money for the goods or services advertised, consumers must trust the communication process of the advertisements displayed [18].

The content can be influenced by several things, such as: (1) depends on certain advertisements that have a higher influence on the company, (2) environmental pressure from competing ad publishers, (3) the larger and more innovative companies have excellence coverage for their products, and (4) the effect of company advertisements in Europe and the United States [16].

\section{Semiotics}

Semiotics is the science of sign which derived from the Greek Semion meaning sign. The term semiotics which was raised by Charles Sanders Pierce refers to the formal doctrine of signs [7]. Sobur went on to say that the basis of semiotics is the concept of signs. The sign is the basis of all communication, according to Little John in Sobur [19]. So, the sign used in the entire communication process can be further elaborated by using semiotics [7].

Semiotic sign is studied individually (microdiscourse) and transferred into sentences (e'nonciation) to tell what is communicated by the brand in a broader cultural discourse (macrodiscourse). Macrodiscourse includes "Voice of Brand" (how the markers and voiced are voiced) and "Positioning Brand" (where the meaning of the brand is placed in a broader cultural context). The aim is to connect brand signs and symbols with broad myths and archetypes drawn from consumer culture [20]. Semiotics does not always focus on the meaning of signs and symbols that are imminent (Saussurean Semiotics) but also on how the meaning of symbols is regenerated in a situation with a broader cultural and social context for the decision of a communicant [21].

\section{RESEARCH METHODS}

This study used a semiotic analysis method. Semiotics is called the science of signs. Semiotics is the study of meaning and analysis of events that produces a meaning. It was selected as a research method, because semiotics could provide a large space for interpretation of advertisements, so that in the end, they can find hidden meanings in an advertisement.

Semiotics does not always focus on the meaning of signs and symbols that are imminent (Saussurean Semiotics) but also on how the meaning of symbols is regenerated in a situation with a broader cultural and social context for the decision of a communicant [21]. Semiotic sign is studied individually (microdiscourse) and transferred into sentences (e'nonciation) to tell what is communicated by the brand in a broader cultural discourse (macrodiscourse). Macrodiscourse includes "Voice of Brand" (how the markers and voiced are voiced) and "Positioning Brand" (where the meaning of the brand is placed in a broader 
cultural context). The aim is to connect brand signs and symbols with broad myths and archetypes drawn from consumer culture [20].

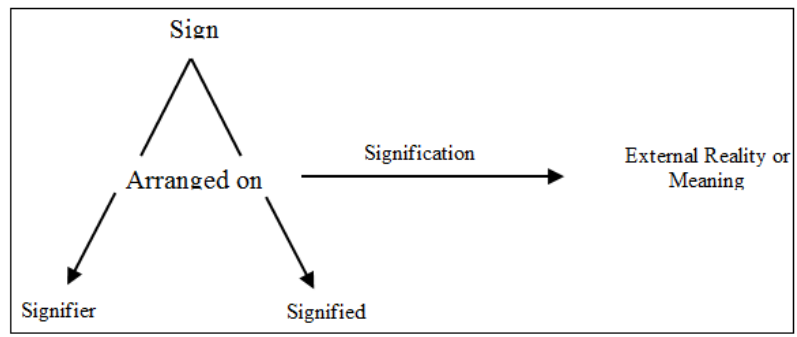

Signifier is a meaningful sound or scribble. Meanwhile, signified is a mental image or concept of something of a signifier. The relationship between the physical existence of a sign or mental concept is called signification. In other words, signification is an effort to give meaning to the world [7].

The object of study in this study was the Ades mineral water advertisement of "Small Step Give a Change" version in television media which has seventeen second duration. The identification of the object of research that has the theme of environmental stewardship is an appeal to the public to consume Ades mineral water and crush the bottle as proof that the packaging bottle used by Ades is a thin and environmentally and friendly bottle. Then the data collection techniques in this study were collecting the primary data and secondary data. Primary data in this study obtained directly through observation of the research object (Ades advertisement of the Small Step give a Change version) in the form of videos that have been downloaded from the internet. In addition, the secondary data obtained from documentation data, archives, and scientific books. In this study, the researchers used scientific books, previous thesis documents, and other sources, such as the official website and the internet to support this research.

Meanwhile, the selection of categorization was based on the basic theory of Peirce's predetermined meaning, this stage of categorization is called the filling system by making categories from the results of observations of the data to be interpreted. By the basic theory of Peirce's triangular meaning, the analysis stages carried out by the researcher are as follows. 1) Identifying the signs contained in Ades Ades version of the Small Steps Providing Changes, 2) Classifying the signs contained in Ades Advertisements of the Small Step Gives a Change version, 3) Interpreting one by one sign using Peirce's triangle meaning and explaining it as a whole, and 4) Explaining the hidden message contained in the Ades Advertisements of the Small Step Gives a Change version constructed through the signs in the ad.

\section{RESULT AND DISCUSSION}

Based on observations of advertisements, signs, and meanings, they were analyzed using Charles S. Peirce's semiotic model explained below:

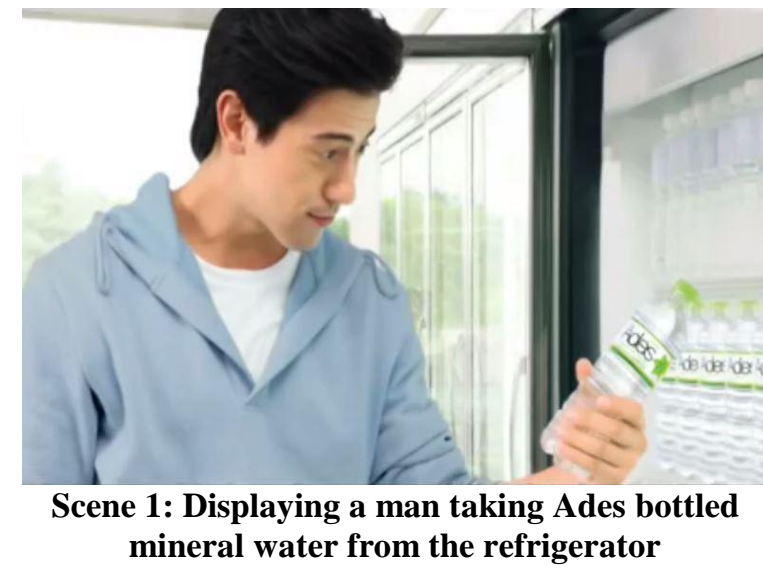

The first scene above shows a man with sporty clothes who has been exercising in the morning, then looks for cold drinks at the supermarket and drops his choice on Ades mineral water. In this scene, it uses the type of medium shot, which is shooting from the waist / navel to the head. The interpretation of the setting in the morning is due to the white color that dominated like fog. Based on the type of clothing used by the man, the researchers argues that a man has been doing sports that are looking for Ades drinks to prevent dehydration and refresh his body.

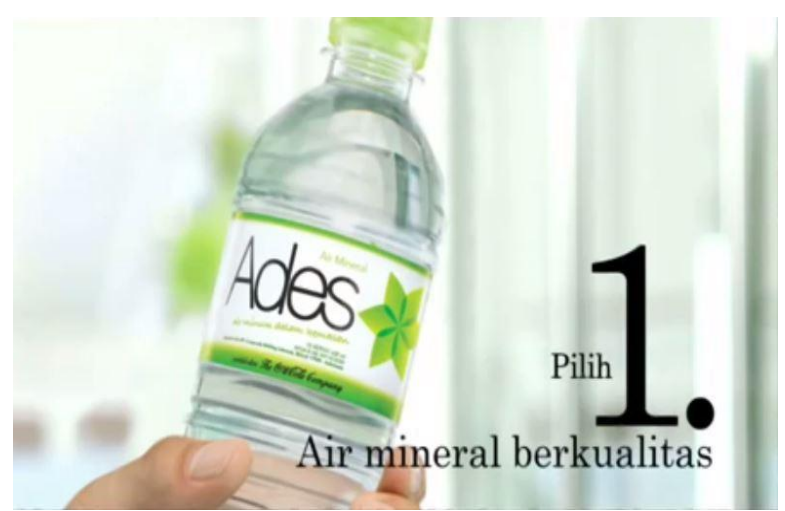

Scene 2: Displaying Ades product packaging that is currently in the handheld

In this second scene, it features the Ades product packaging that is being held by a man and the logo from the Ades packaging. This scene taken used the Close Up shooting technique, which was a picture taken from a camera shot very close to the object. Close Up was used so that the viewer focused on this part and overrided the other parts. In this scene, there are two objects, the first clearly visible bottle of Ades being held by a man after taking it from the fridge. According to the interpretation of researchers, this scene has the strength of the product promotion of the Ades ad of "Small Step Gives a Change" version and illustrates that the Ades packaging bottle is easy to hold / hold. Then 
the second sign is the word "choose 1 qualified mineral water" which means that Ades is the number one bottled mineral water that has the better quality than other bottled mineral water. As in the previous scene, the white color still dominates the background which gives a clean and fresh impression in the morning.

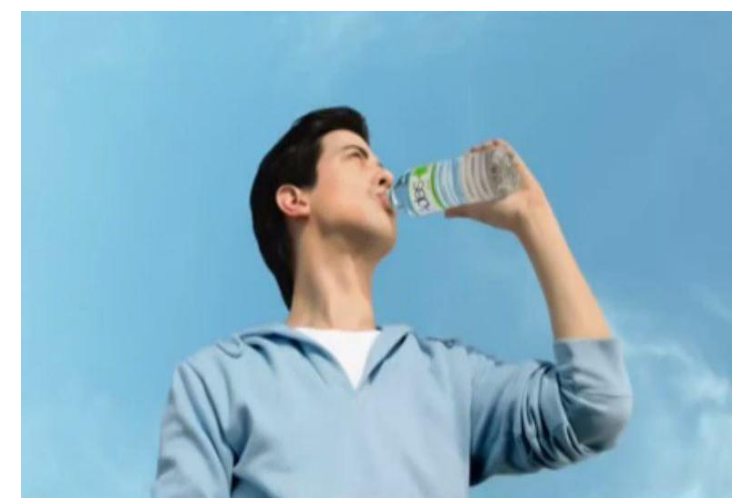

Scene 3: Displaying a man drinking water of Ades

This third scene shows a man wearing sporty clothes enjoying ades bottled water with a blue sky. The shooting technique uses the Medium Close Up technique, which is taking pictures from the subject matter chest to the top of the head. Half-body portrait with the flexibility of the background that can still be enjoyed, and by using Low Angle techniques or taking pictures taken from under the object where the camera is placed at a lower angle than the subject to display the subject's position is higher than the audience.

According to the interpretation of researchers, the scene depicts a man enjoying the fresh-cold drinking water Ades and enjoy the beautiful blue sky visible from the eyes of a man who looks up at the sky.

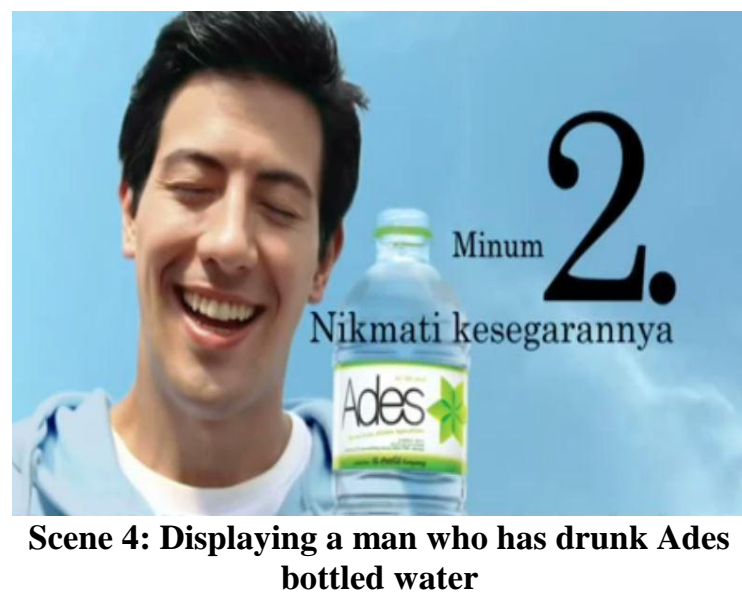

In this fourth scene, a man is drinking ades mineral water which has a statement "Drink 2 Enjoy the Freshness". This shooting technique uses the Close Up technique, which is a remote camera shot, and full view to give the effect of distance and the camera shot is very close to the object. The researchers' interpretation of the scene is a man who looks happy and fresh after drinking Ades mineral water. The blue background depicts a healthy and clean air free from pollution. The meaning of the writings in the picture according to the researchers is to invite the audience to drink two Ades to enjoy the real freshness.

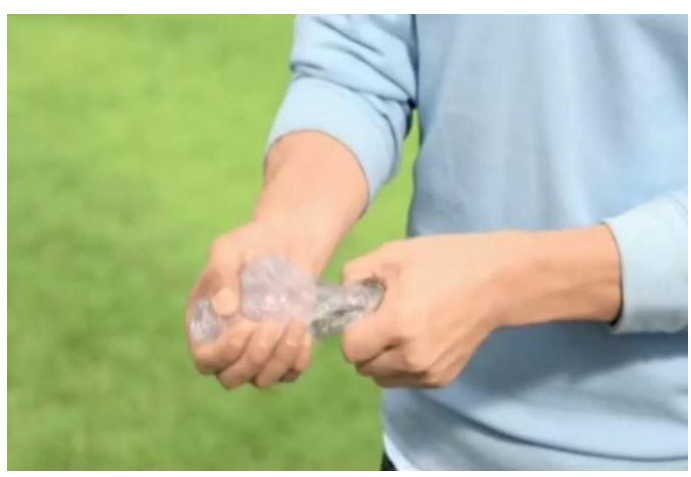

Scene 5: Displaying a man crushing a bottle of Ades

This fifth scene depicts a man crushing an Ades bottle with a green background. These shooting techniques are Close Up and Point of View. Based on the previous explanation, the camera shot is from the subject's point of view and seeing things the way the subject sees it. The researchers' interpretation in this section is that the advertiser wants to show that the Ades bottle has a thin packaging, so that it is very easily crushed and also wants to inform that the ades packaging does not use much plastic material so it is very easy to recycle.

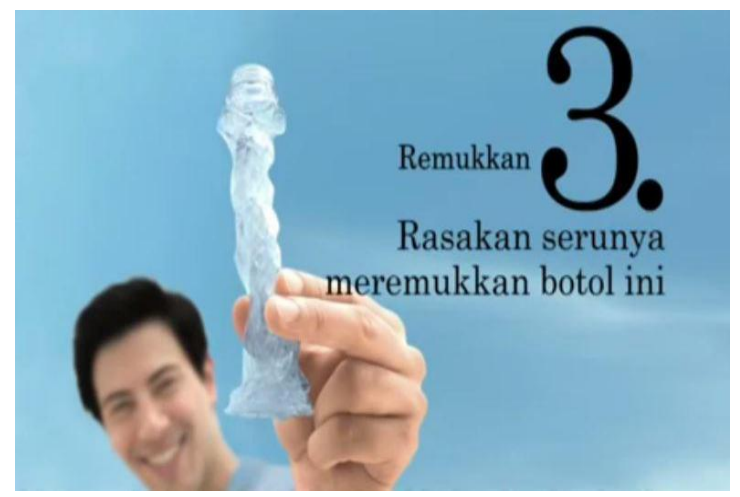

Scene 6: Displaying a man showing a crushed bottle

This sixth scene depicts a man who is showing a broken bottle and has the words "Crush 3 Feel the thrill of breaking this bottle". The shooting technique in this scene is Close Up and High Angle which means the camera is placed at a higher angle than the subject to display the subject's position which is lower than the viewer, and has a dramatic meaning that is small and stunted. Researchers can interpret that Ades bottles are very easy to crush and give more space to throw into the trash. Then the researchers argued that the writing "Crush 3 Feel the thrill of crushing this bottle" can persuade the audience to take part in crushing the Ades bottle so that no accumulation of garbage in the future. 


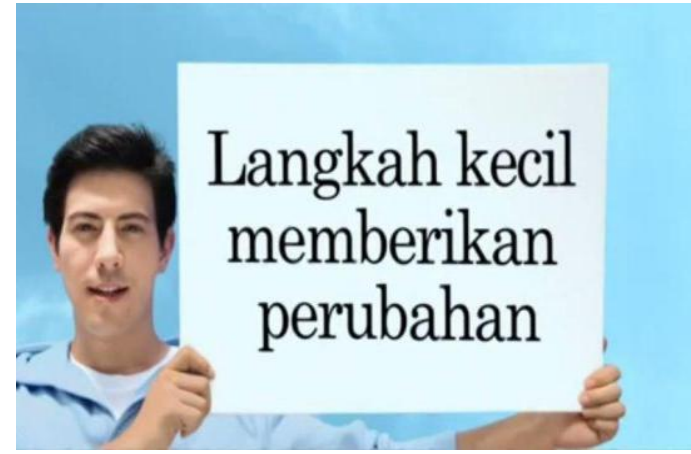

Scene 7: Displaying a man showing the Tagline of Ades

This seventh scene shows a man who is showing the tagline of Ades which is "Small Steps Providing Change" The gaze of a man's eyes indicates the seriousness and confidence in showing the Ades tagline. The shooting technique is included in Medium Close Up which means the camera shot is close enough to the subject, but includes other objects that are close by. Then, in this scene, the sea blue color dominates, the blue color can communicate belief and strength. Related to the interpretation of the scene, Ades tries to communicate the tagline that they carry through the scene in this advertisement by dominating the blue color that promotes a sense of peace and relaxation. Meanwhile, the interpretation of the tagline is Ades provides 3 easy steps "Select-Drink-Crush" as explained in the meaning of the sign in the previous scenes, and these 3 easy steps can provide changes to the environment.

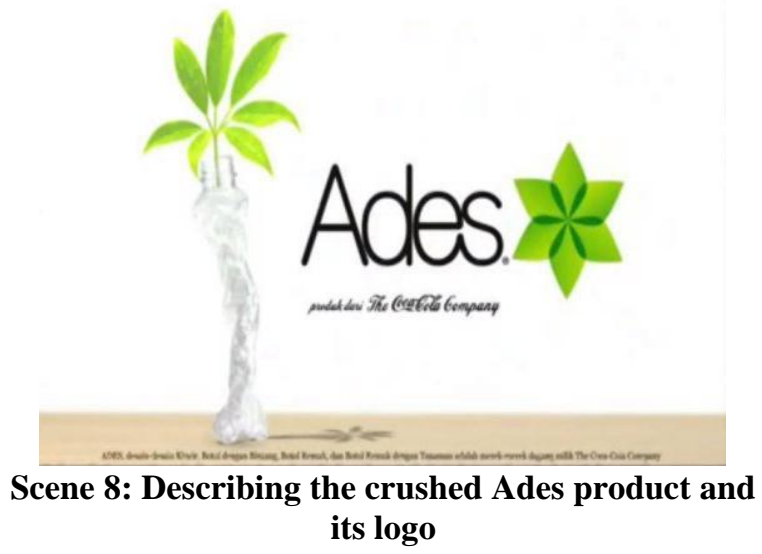

This scene focuses on the emergence of Ades mineral water products with the Ades tagline that appears audio. The technique of shooting in this scene uses a Close Up shot. Researchers interpreted the green and white color on the product packaging, because this scene promoted a product that had been dominantly compiled as the final part of the advertisement. In accordance with the nature of the color associated with the product, green color characterizes the product that is down to earth, peaceful, and environmentally friendly based on the Ades packaging that carries Eco-Green.
Meanwhile the white color, it broadcasts pure, clean mineral water products, and communicates freshness.

The green and white stimulates the eyes, Ades wants people to be aware of their important existence as a pathway to change for the earth throdugh the action of 3 small steps for the changes carried by Ades in the ad. Through green and white, Ades established as a mineral water product with an environmentally friendly packaging that is very important to consume by reducing the use of plastic in its packaging. Ades also invites consumers to supply a small step for the environment through three easy and exciting rituals, namely choose, drink and crush that will give more space in the trash.

Based on the explanation of each scene in the ad, the researcher can describe that the advertisement is very important in influencing the audience. This is as Pilliang said that advertising is a form of spectacle that accompanies a product, which offers images of the values and moral values of society (good / bad, right / wrong). Meanwhile, the image, as Haug said, is actually a series of illusions injected on a commodity in controlling consumers, such as an anesthetic injection. Advertising is a main viewing system in the consumer consumption production system [22].

It is different from the information of object or service, advertising has the nature of "pushing" and "persuading" so that we remember, like to choose, and then buy it. Advertising restrictions can be seen as a form of communication that consists of information and ideas about a product that will be aimed at the audience simultaneously in order to get a good reception. In the midst of business competition, the public is presented with one type of new advertising genre, namely Corporate Social Responsibility (CSR) advertisement. This advertisement is the Public Relations strategy in creating a positive issue of a company which is sheltered to the public, looking at the broad scope of public relations targets.

One of the companies that uses CSR advertisements is Ades which has positioned as a company that cares about the environment. In the Ades version of "Small Step Gives a Change", Ades also includes linear steps for consuming Ades mineral water to be an attraction in the ad. Ades uses the concept of Story Telling by emphasizing the concept of pictures taken from the place of shooting, color, color grading, to the actor, by showing a fresh and natural atmosphere, a short story of a man who with physical condition who is fit to drink Ades drinking water. In addition, the Ades version of "Small Step Gives a Change" ads on television was created and packaged by including elements of persuasion messages to show ADES's commitment to the environment. 
An attitude towards advertising arises when we make more understanding of the advertisement. Therefore, researchers have conducted a study to interpret the message contained in the Ades advertisement of "Small Step Gives a Change" version in television media. Researchers used the Semiotics research method by Charles S. Peirce to find out the meaning of the messages conveyed in the Ades advertisement of "Small Step Gives a Change" version. Peirce classifies the types of signs into three types, such as, representamen, objects and interpretants, that allow researchers to delve deeper meaning and visual language contained in the Ades advertisement of "Small Step Gives a Change" version in Television Media.

In the Ades advertisement of "Small Step Gives a Change" version in television media, researchers found the meaning that wanted to be built in the advertisement. In the advertisement, there is a fit and sporty person. The purpose is to give the impression to the audience, that those who drink ades mineral water, get good impact on physical health. Then, there is the background of the room which is dominated by white, showing that Ades is a hygienic beverage product.

In the next scene when the bitter melon drinks Ades products, there is a garden with green grass that becomes the background. The impression to be conveyed is that when drinking ades, the body will feel refreshed. At the end, the man crushed the empty Ades packaging bottle, the aim is to show that the plastic packaging used by Ades is not too thick, so that it can reduce the use of plastic which is a negative issue at this time.

In the advertisement, the narrative used is an invitation to consume drinking bottle that uses minimum amount of plastic. From all of these advertisements, Ades wants to communicate that ades is a hygienic beverage product uses plastic packaging and still cares about the environment as in the narration created at the end of the ad's sentence "SMALL STEP GIVES A CHANGE".

\section{CONCLUSION}

Based on research that has been obtained on the results of research and discussion on the meaning of the messages contained in the Ades advertisement of "Small Step Gives a Change" version in television media, it can be concluded that through the finding of signs in Ades ads, it is implied hidden messages about environmental care. Ades wants to show that the mineral water is of high quality and provides solutions to the public in protecting the body. Broadly speaking, the advertisements' meaning show the commitment of Coca-Cola Amatil Indonesia towards sustainable packaging. The sustainable means that through the environmentally and friendly ADES packaging, it can have a positive impact on the environment sustainability.

Through advertising, Ades urges consumers to start a small step that can make a difference to the environment. The ad introduces the easy-to-do jargon of "choose, drink and crush". Crushing the mineral water bottles that have been consumed will leave plenty of room for plastic waste with environmentally friendly packaging. The the Ades advertisement of "Small Step Gives a Change" version proves that advertising is not just a promotional and selling tool, but through a hidden message on Ades ads, it can encourage people to start a small step to make a difference for the environment.

Suggestions that the researcher can give related to the results of this study is expected to provide information or an overview related to the meanings contained in the the Ades advertisement of "Small Step Gives a Change" version in television media and can be a comparison about the power of these advertisements which might result in different interpretations. By this many interpretations, it will further enrich and broaden our view and the practical suggestions of this research are expected so that Ades can create youtube and other social media versions with a longer duration that can convey more interesting and informative messages. Furthermore, it hopes that Ades will be able to enrich his CSR elements by strengthening his campaign through visualization.

\section{REFERENCES}

1. Sumartono. (2002). Terperangkap Dalam Iklan, Alfabeta: Bandung.

2. Danesi, M. (2010). Pengantar Memahami semiotika Media. Yogyakarta: Jalasutra.

3. Sobur, A. (2004). Semiotika Komunikasi (cetakan kedua). Bandung: Remaja Rosa Karya.

4. Kriyantono, R. (2006). Teknik Praktis Riset Komunikasi. Jakarta: Kencana.

5. Morissan. (2010). Periklanan: Komunikasi Pemasaran Terpadu, Jakarta: Kencara Prenada Media Group.

6. Putra, A. M., \& Hariyati, D. (2019). The Strategy of native on the metro advertising plus programs in supporting ads revenue on metro TV. International Journal of Humanities and Social Science Research, 5(4); 71-77.

7. Sobur, A. (2009), Semiotika Komunikasi, Bandung: PT Remaja Rosdakarya.

8. Rakhmat, J. (20030 Psikologi Komunikasi, Bandung: Remaja Rosdakarya.

9. Elvinaro Ardinato, Lukiati Komala, Siti Karmila, 2012, Komunikasi Suatu Pengantar Edisi Revisi, Bandung: Simbiosa Rekatama Media.

10. Ells, K. (2018). Breaking "News": Majority Can't Define Mass Communication, Journalism \& Mass Communication Educator, 1-10.

11. Postmes, T., \& Brunsting, S. (2002). Collective action in the age of the Internet: Mass 
communication and online mobilization. Social Science Computer Review, 20(3), 290-301.

12. Weingart, S. N., Callanan Jr, L. D., Ship, A. N., \& Aronson, M. D. (2001). A physician- based voluntary reporting system for adverse events and medical errors. Journal of General Internal Medicine, 16(12), 809-814.

13. Bauer, W. D., Talmadge, K. W., Keegstra, K., \& Albersheim, P. (1973). The structure of plant cell walls: II. The hemicellulose of the walls of suspension-cultured sycamore cells. Plant physiology, 51(1), 174-187.

14. Schmitt, K. M., Gunther, A. C., \& Liebhart, J. L. (2004). Why Partisans See Mass Media as Biased. Communication Research, 31(6), 623-641.

15. Noviani, R. (2002). Jalan Tengah Memahami Iklan. Yogyakarta: Pustaka Pelajar.

16. Rinallo, D., \& Basuroy, S. (2009). Does advertising spending influence media coverage of the advertiser?. Journal of Marketing, 73(6), 33-46.
17. Kucuk, S. U. (2008). Negative Double Jeopardy: The Role of Anti-Brand Sites on the Internet. Journal of Brand Management, 15(3), 209-22.

18. Davis, J. J. (1994). Environmental advertising: Norms and levels of advertiser trust. Journalism Quarterly, 71(2), 330-345.

19. Sobur, A. (2013). Filsafat Komunikasi: Tradisi dan Metode Fenomenologi. Bandung: Remaja Rosdakarya.

20. Oswald, L. R. (2012). Marketing Semiotics. New York: Oxford University Press.

21. Mick, D. G., Burroughs, J. E., Hetzel, P., \& Brannen, M. Y. (2004). Pursuing the meaning of meaning in the commercial world: An international review of marketing and consumer research founded on semiotics. Semiotica, 2004(152-1/4), 174.

22. Piliang, Y. A., \& Adlin, A. (2003). Hipersemiotika: tafsir cultural studies atas matinya makna. Jalasutra. 